\title{
EFEKTIFITAS PENGGUNAAN METODE BERMAIN DI PAUD NAZARETH OESAPA
}

\author{
Oleh: \\ Salmon Amiran \\ email: salmonamtiransa@gmail.com \\ Prodi IPS, Program PascaSarjana, Universitas Nusa Cendana Kupang
}

\begin{abstract}
Abstrak
Permasalahan yang diangkat dalam penelitian ini adalah "Bagaimana efektifitas penggunaan metode bermain di PAUD Nazareth Oesapa?". Adapun tujuan yang akan dicapai dalam penelitian ini adalah untuk mengetahui efektifitas penggunaan metode bermain di PAUD Nazareth Oesapa. Dalam menganalisis data penulis menggunakan teknik penelitian kualitatif adalah merupakan proses mencari dan menyusun secara sistematis data yang diperoleh dari hasil pengamatan (observasi), wawancara, catatan lapangan, dan studi dokumentasi, dengan cara mengorganisasikan data ke sintesis, menyusun ke dalam pola, memilih mana yang penting, dan mana yang dipelajari, dan membuat kesimpulan sehingga mudah dipahami oleh diri sendiri maupun orang lain. Metode pengumpulan data yang penulis gunakan adalah Observasi, Wawancara, dan Studi Dokumentasi.

Hasil penelitian menunjukan bahwa metode bermain dapat membantu anak dalam meningkatkan daya imajinasi, kemampuan fisik motorik halus dan kasar, keterampilan sosial, kognitif, emosi melalui metode bermain anak dapat dibimbing dan diarahkan. Anak dapat mengikuti aturan permainan, mendengarkan penjelasan materi permainan dengan tenang, senang dan kerjasama dan anak dapat menumbuhkan minat dan kreativitas anak sehingga kegiatan permainan tidak membosankan.
\end{abstract}

Kata kunci: Metode Bermain

\section{Abstract}

Issues raised in this research is "How can the effectiveness of using the method to play in PAUD Nazareth Oesapa?". The objectives to be achieved in this study was to determine the effectiveness of using the method to play in PAUD Nazareth Oesapa. In analyzing the data the authors use qualitative research techniques is a process of searching for and compiling a systematic data obtained from observations (observation), interviews, field notes, and documentation study, by way of organizing data into synthesis, organize into a pattern, choose which one important, and what is learned, and make conclusions so easily understood by myself and others. Data collection methods that I use is observation, interview, and documentation Studies. The results showed that the method can help children play in increasing the power of imagination, physical ability fine and gross motor skills, social skills, cognitive, emotional through methods of playing children can be guided and directed. Kids can follow the rules of the game, listening to the game with the matter quiet, happy and cooperation and the child can grow the interest and creativity of children so that the activities of the game is not boring.

Keywords: Playing Method

PENDAHULUAN

Anak merupakan amanah sekaligus karunia Tuhan Yang Maha Esa, yang senantiasa dijaga harkat, martabat dan hak asasi yang melekat sejak anak dilahirkan.
Anak memerlukan kasih sayang, pembinaan, bimbingan khusus agar dapat berkembang fisik, mental, spiritualnya secara maksimal. Anak adalah investasi yang sangat besar bagi keluarga dan juga 
bangsa. Anak-anak adalah generasi penerus keluarga sekaligus penerus bangsa. Di tangan-tangan penerus bangsa inilah sejarah negara Indonesia akan dilukiskan. Jika para generasi penerus baik, maka akan baik pula negara yang dipimpinnya. Namun untuk mewujudkan generasi yang baik ini tidaklah semudah membalikan telapak tangan. Dibutuhkan pengorbanan dan perjuangan yang cukup besar baik dari lingkungan keluarga (orang tua) dan lingkungan sekolah (guru) untuk mencapainya.

Masa anak-anak adalah jendela kesempatan emas bagi berbagai peluang tumbuh kembang anak yang tidak terulang, baik secara fisik, emosional dan sosial. Kurangnya perhatian pada masa anak-anak bahkan sejak usia dini mempunyai pengaruh yang terbawa hingga dewasa. Seperti apa seorang anak pada masa dewasanya sangat bergantung seberapa perhatian, kasih sayang, dan kepentingan terbaiknya yang diterima bahkan sejak usia dini (Budiardjo, 2011).

Bermain merupakan tuntutan dan kebutuhan psikologis dan biologis anak yang sangat penting. Melalui bermain, tuntutan akan kebutuhan perkembangan dimensi perkembangan motorik, kognitif, kreatifitas, bahasa emosi, interaksi sosial, nilai-nilai dan sikap hidup, dapat terpenuhi. bermain-main adalah ekspresi dan hiburan, yang mencakup kesenangan dan tujuan, Baik tubuh dan pikiran. Bermain adalah suatu cara bagi anak-anak untuk belajar tentang benda-benda dan berhubungan dengan orang lain (Sujiono, 2006).

Bermain dapat memberikan kesempatan kepada anak untuk memahami dunia, berinteraksi dengan anak lain, mengekspresikan dan mengendalikan emosi, dan mengembangkan kemampuan simbolik sehingga anak aktif membangun pengetahuannya. Perkembangan anak semakin maju jika anak memiliki kesempatan untuk praktek keterampilanketerampilan yang diperolehnya. Bermain akan banyak melibatkan anak dalam berbagai aktivitas, sehingga konsepkonsep yang akan diajarkan dapat ditangkap dengan cepat dan mampu bertahan dalam memori anak (Maryatun dan Hayati, 2010).

Banyak orang kurang mengetahui bahwa bermain merupakan bagian paling penting dalam kehidupan seorang anak, terutama usia balita dan usia sekolah. Gejala-gejala umum yang tampak terutama di kota-kota, anak-anak malah dijejali berbagai kegitan, baik akademis maupun non akademis untuk mengejar prestasi. Akibatnya banyak waktu anak-anak tersita untuk mengerjakan berbagai tugas sekolah maupun mengikuti bermacam-macam les yang belum tentu mereka suka. Anak mungkin terpaksa melakukan hal itu untuk sekedar memenuhi ambisi orang tuanya padahal anak-anak perlu diberi kesempatan untuk bermain dan berkreasi, yang tujuannya sama penting dengan belajar (Sujiono, 2006).

Bermain selalu berdasarkan inisiatif anak, kemauan anak dan dukungan guru, sehingga guru berperan sebagai fasilitator yang senantiasa siap melayani anak sesuai dengan kebutuhannya. Belajar dan bermain bagi anak menjadi menyenangkan dalam bentuk kegiatan sehari-hari yang dirancang untuk anak-anak. Kesenangan bermain yang tidak terhalang melepaskan segala macam perilaku negatif yang ada dalam diri anak, melatih kesehatan, dan membuat anak merasa penuh kenyamanan. Dalam permainan anak dapat mengekspresikan dirinya dan sosialitas. Bermain bukan saja bahagia, tetapi kreatif dan inovatif.

Melalui bermain ditanamkan beragam nilai dan aturan hidup. Bermain sungguh memberi efek yang sangat kuat dan positif bagi pertumbuhan otak dan seluruh kemanusiaan anak.

\section{Pengertian Bermain}

Dalam kamus Bahasa Indonesia, bermain didefinisikan sebagai melakukan sesuatu untuk bersenang-senang. jadi seorang anak yang sedang bermain berarti 
itu sedang melakukan suatu aktivitas yang menyenangkan dirinya. Bermain itu menyenangkan karena dalam bermain anak bebas mengekspresikan perasaanperasaanya, ide-ide ataupun fantasifantasinya kadang tidak selaras dengan kenyataan yang sebenarnya (Sujiono, 2006). Hurlock (1978) mendefinisikan bermain sebagai aktivitas-aktivitas untuk memperoleh kesenangan. Lebih lanjut Hurlock (1978) menegaskan bermain merupakan lawan dari kerja. Jika bermain dilakukan dengan kesenangan dan kebahagiaan, maka bekerja belum tentu harus dilakukan dengan dengan bahagia, jika bermain dilakukan dengan tanpa beban, maka bekerja harus dilakukan dengan beban kewajiban tertentu, jika bermain dilakukan dengan tanpa tujuan atau hasil, maka bekerja selalu berorientasi pada hasil.

Bermain adalah kegiatan yang sangat penting bagi pertumbuhan dan perkembangan anak. Bermian harus dilakukan atas inisiatif anak dan atas keputusan anak sendiri (Mutiah, 2010). Bermain harus dilakukuan dengan rasa senang, sehingga semua kegiatan bermain yang menyenangkan akan menghasilkan proses belajar pada anak. Masitoh (2007) bermain suatu kegiatan yang melekat pada dunia anak. Bermain adalah kotrat anak. Solehuddin (1996) menyatakan bahwa pada intinya, bermain dapat dipandang sebagai suatu kegiatan yang bersifat volunter, spontan, terfokus pada proses, memberikan ganjaran secara intrinsik, menyenangkan dan fleksibel. Yus (2011) bermain merupakan suatu yang menyenangkan. Hampir tidak ada permainan yang membuat anak tidak senang. Kadangkala, ia berlama-lama dalam satu permainan, pada saat yang lain ia bermain sesaat atau sebentar saja. Dalam bermain anak melakukan berbagai kegiatan yang berguna untuk mengembangkan dirinya. Anak mengamati, mengukur, membandingkan, bereksplorasi, meneliti, dan masih banyak lagi yang dilakukan anak. Situasi seperti sering dilakukan, tanpa disadari bahwa ia telah melatih dirinya dalam beberapa kemampuan tertentu sehingga ia memiliki kemampuan baru.

Menurut Linda (2006) bermain merupakan peluang bagi anak untuk melakukan berbagai hal. Situasi itulah yang membuat anak belajar. Belajar tentang apa saja. Bermain tentang objek, kejadian, situasi dan konsep misalnya: halus dan kasar. Anak juga berlatih koordinasi berbagai otot gerak misalnya otot jari. berlatih mencari sebab akibat dan memecahkan masalah. selain itu, melalui bermain anak berlatih mengekspresikan perasaan, dan berusaha mendapatkan sesuatu.

Berdasarkan beberapa pendapat di atas penulis dapat menyimpulkan bermain merupakan berbagai macam bentuk kegiatan yang memberikan kepuasan pada diri anak dalam mengamati, mengeksplorasi, berhayal, bahagia, berinteraksi, dalam mengungkapkan segala pikiran dan perasaan yang ada dalam diri anak itu sendiri.

\section{Fungsi Bermain}

Fungsi bermain sebagai berikut: Moeslichatoen (2004): a) Menirukan apa yang dilakukan oleh orang dewasa. b) Untuk melakukan berbagai peran yang ada dalam kehidupan nyata. c) Untuk mencerminkan hubungan dalam keluarga dan pengalaman hidup yang nyata. d) Untuk menyalurkan perasaan yang kuat. e) Untuk melepaskan dorongan-dorongan yang tidak dapat diterima. f) Untuk kilas balik perang-peran yang biasa dilakukan. g) Mencerminkan Pertumbuhan. h) Untuk memecahkan masalah dan mencoba berbagai penyelesaian.

\section{Manfaat Bermain}

Manfaat bermain sebagai berikut:

a) Manfaat bermain untuk perkembangan aspek fisik.

Ketika bermain anak mendapat kesempatan untuk melakukan kegiatan yang banyak melibatkan gerakan- 
gerakan tubuh, sehingga membuat tubuh anak menjadi sehat. selain itu, anggota tubuh mendapat kesempatan untuk digerakkan, dan anak juga dapat menyalurkan tenaga (energi) yang berlebihan sehingga anak tidak merasa gelisah.

b) Manfaat bermain untuk perkembangan aspek motorik kasar dan motorik halus.

Aspek motorik kasar dapat dikembangkan melalui kegiatan bermain, misalnya anak yang bermain kejar-kejaran untuk menangkap temannya. Aspek motorik halus dapat dikembangkan melalui kegiatan bermain mewarnai, menggambar bentuk-bentuk tertentu atau meronce berbagai bentuk dengan variasi berbagai bahan.

c) Manfaat bermain untuk perkembangan aspek sosial.

Dengan bermain anak belajar berkomunikasi dengan sesama teman baik dalam hal mengemukakan isi pikiran dan perasaannya maupun memahami apa yang diucapkan oleh teman, sehingga hubugan dapat terbina dan dapat saling tukar informasi.

d) Manfaat bermain untuk perkembangan aspek emosi atau kepribadian.

Melalui bermain anak dapat melepaskan ketegangan yang dialaminya dalam hidupnya sehari-hari. Selain itu, bermain bersama sekelompok teman anak akan mempunyai penilaian terhadap dirinya sehingga dapat membantu pembentukan konsep diri, rasa percaya diri, dan harga diri karena ia merasa mempunyai kompetensi tertentu.

e) Manfaat bermain untuk perkembangan aspek kognitif.

Pada usia dini anak diharapkan menguasai berbagai konsep seperti warna, ukuran, bentuk, arah, besaran sebagai landasan untuk belajar menulis, bahasa, matematika, dan ilmu pengetahuan sosial. Pemahaman konsep-konsep ini lebih mudah diperoleh jika dilakukan melalui kegiatan bermain.

f) Manfaat bermain untuk mengasah ketajaman penginderaan.

Penginderaan menyangkut penglihatan, pendengaran, penciuman, pengecapan, dan perabaan. Melalui kegiatan bermain kelima aspek penginderaan dapat diasah agar anak menjadi lebih tanggap atau peka terhadap hal-hal yang berlangsung di lingkungan sekitarnya.

g) Manfaat bermain untuk mengembangkan keterampilan olah raga dan menari.

Dalam kegiatan bermain olahraga anak melakukan gerakan-gerakan olahraga seperti berlari, melompat, menendang dan melempar bola sehingga anak akan memiliki tubuh yang sehat, kuat dan cekatan. Dalam kegiatan menari anak melakukan gerakan-gerakan yang lentur dan tidak canggung-canggung sehingga anak akan memiliki rasa percaya diri (Sujiono, 2010).

\section{Pengertian Pendidikan Anak Usia Dini}

Menurut Masitoh dkk (2007)

Pendidikan anak usia dini merupakan bentuk pendidikan yaitu anak yang berusia 0 sampai dengan 6 tahun. Pendidikan memiliki peran yang sangat penting untuk mengembangkan kepribadian anak serta mempersiapkan mereka untuk memasuki jenjang pendidikan selanjutnya. Pendidikan anak usia dini merupakan jembatan antara lingkungan keluarga dan masyarakat yang lebih luas yaitu sekolah dasar dan lingkungannya.

$$
\text { Undang-undang Sistem }
$$

Pendidikan Nasional tahun 2003 pada pasal 1 ayat 14 menyatakan bahwa pendidikan anak usia dini adalah suatu upaya pembinaan yang ditujukan kepada anak sejak lahir sampai dengan usia enam tahun yang dilakukan melalui pemberian rangsangan pendidikan untuk membantu pertumbuhan dan perkembangan jasmani dan rohani agar anak memiliki kesiapan dalam memasuki pendidikan lebih lanjut. Pendidikan anak usia dini pada hakekatnya 
adalah pendidikan yang diselenggarakan dengan tujuan untuk memfasilitasi pertumbuhan dan perkembangan anak secara menyeluruh atau menekankan pada pengembangan seluruh aspek kepribadian anak. Pendidikan anak usia dini memberi kesempatan kepada anak untuk mengembangkan kepribadiannya. Oleh karena itu, pendidikan anak usia dini perlu menyediakan berbagai kegiatan yang dapat mengembangkan berbagai aspek perkembangan yang meliputi: kognitif, bahasa, sosial, emosi, fisik, dan motorik (Masitoh dkk, 2007).

Berdasarkan pendapat beberapa di atas penulis dapat menyimpulkan bahwa Pendidikan anak usia dini adalah sebuah upaya yang dilakukan guru untuk diberikan kepada anak usia 0 sampai dengan 6 tahun dalam mempersiapakan anak memesuki pendidikan lebih lanjut.

\section{METODE}

Jenis penelitian yang digunakan penulis adalah jenis penelitian deskriptif kualitatif yaitu: prosedur penelitian menghasilkan data deskriptif berupa katakata tertulis maupun lisan dari orang-orang dan perilaku yang diamati. Penelitian kualitatif dilakukan pada kondisi alamiah dan bersifat penemuan. Dalam penelitian kualitatif, peneliti adalah instrumen kunci (Moleong, 2007).

Menurut Iskandar (2009:121) pengumpulan data dalam penelitian kualitatif dapat dilakukan oleh peneliti dengan menggunakan beberapa teknik. Dalam penelitian kualitatif teknik pengumpulan data yang paling populer digunakan lebih banyak pada observasi, wawancara dan dokumentasi. Untuk mendapatkan data atau keterangan sesuai dengan masalah yang diteliti, maka penulis menggunakan teknik pengumpulan data sebagai berikut:

1. Observasi

Observasi adalah melakukan pengamatan, pencatatan secara sistematik, kejadian-kejadian, perilaku, objek-objek yang dilihat dalam hal lain yang diperlukan dalam mendukung penelitian yang sedang dilakukan (Iskandar, 2009:121).

2. Wawancara

Wawancara merupakan bentuk komunikasi antara peneliti dengan subjek yang diteliti dengan mengajukan pertanyaan-pertanyaan dalam mencari informasi berdasarkan tujuan (Iskandar, 2009:212).

3. Studi Dokumentasi

Studi dokumentasi merupakan pencarian data mengenai hal atau variabel yang berupa catatan, transkip, buku, surat kabar, majalah, agenda dan lain sebagainya (Arikunto, 2005).

Sugiyono (2012) menyatakan analisis data kualitatif merupakan proses mencari dan menyusun secara sistematis data yang diperoleh dari hasil pengamatan (observasi), wawancara, catatan lapangan, dan studi dokumentasi, dengan cara mengorganisasikan data ke sintesis, menyusun ke dalam pola, memilih mana yang penting, dan mana yang dipelajari, dan membuat kesimpulan sehingga mudah dipahami oleh diri sendiri maupun orang lain.

Untuk menganalisis data, penulis menggunakan teknik analisis kualitatif. Sesuatu telaah dengan menggunakan pemikiran logis dan sistematis untuk menggambarkan atau melukiskan permasalahan dan fenomena yang ada serta menjelaskan secara menyeluruh berdasarkan fakta-fakta yang ada di lapangan. Di dalam teknik ini lebih banyak dianalisis dengan kata-kata ketimbang angka-angka yang berdasarkan pada jawaban responden di lapangan.

\section{PEMBAHASAN}

Bermain merupakan hal penting yang dibutuhkan anak untuk dapat mengembangkan perkembangan anak. Bermain ini sangat penting bagi anak sehingga anak dapat mengenal bentuk, warna, dan dapat meningkatkan daya imajinasi, kemampuan fisik motorik halus dan kasar, kemampuan kognitif dan 
kemampuan sosial anak sebagai bekal anak dalam menggapai masa depan nanti. Di PAUD, bermain sangat penting bagi anak untuk diperhatikan.

Berdasarkan hasil observasi dan wawancara tanggal 2 juni 2016 dan pendapat Linda (2006) menunjukkan bahwa anak dalam meningkatkan daya imajinasi, kemampuan fisik motorik halus dan kasar, keterampilan sosial, kognitif, emosi melalui metode bermain anak dapat dibimbing dan diarahkan. Anak dapat mengikuti aturan permainan, mendengarkan penjelasan materi permainan dengan tenang, senang dan kerjasama. Mengunakan permainan dapat menumbuhkan minat dan kreativitas anak sehingga kegiatan permainan tidak membosankan. Kegiatan permainan disini membantu anak dalam meningkatkan keterampilan sosial, kognitif dan emosi sehingga anak tidak bosan untuk berlatih.

Metode bermain ini adalah kegiatan yang sesuai untuk melatih kerjasama yang ada pada diri anak, kreativitas anak untuk bermain dan menyelesaikan permainannya akan membantu anak menumbuhkan interaksi dengan teman dalam kelompok bermainnya. Dalam kegiatan bermain yang sudah dilakukan dalam setiap kegiatan, guru-guru selalu menyisipkan contoh kegiatan yang dapat dikembangkan anak dalam peningkatan daya imajinasi, kemampuan fisik motorik halus dan kasar, keterampilan sosial, kognitif dan emosi anak. guru-guru juga mengajak anak untuk kreatif dalam menyelesaikan permainan tersebut dan sejalan dengan keinginan anak, cara anak melakukan permainan berinteraksi atau bekerjasama ketika kegiatan berlangsung.

Metode bermain memberikan kesempatan kepada anak untuk mengembangkan kreativitas, maka berarti kreativitas itu bisa tampil dini dalam kehidupan anak dan terlihat pada saat ia bermain, karena ketika bermain anak berimajinasi dan mengeluarkan ide-ide yang tersimpan di dalam dirinya. Anak mengekspresikan pengetahuan yang dia miliki tentang dunia dan kemudian juga sekaligus bisa mendapatkan pengetahuan baru, dan semua dilakukan dengan cara menggembirakan hatinya. Bermain juga menambah daya ingat dan kesempatan menalar, inilah sebabnya bermain dapat membantu penyelesaian diri yang baik dalam kehidupan karena anak belajar mengatasi masalah sehari-hari dari hasil bermain tersebut namun demikian mekanisme permainan yang dapat merangsang kreativitas anak belum di ketahui secara jelas.

Berdasarkan obeservasi tanggal 5 juni 2016 dapat disimpulkan bermain adalah metode yang dapat membantu penyaluran kelebihan tenaga untuk memperoleh keseimbangan antara kegiatan dengan menggunakan kekuatan tenaga dan kegiatan yang memerlukan ketenangan.

Kelebihan metode bermain :

Anak lebih senang dan tertarik, b) Dapat diikuti oleh seluruh anak, c) Meningkatkan keterampilan berhubungan dengan anak lain, d) Guru dapat berinteraksi langsung dengan anak, e) Menyempurnakan keterampilan-keterampilan yang dipelajari, f) Guru dapat langsung mengkelompokkan kegiatan bermain

Metode bermain ini merupakan wujud dari penyaluran kegiatan PAUD Nazareth Oesapa. Dengan bermain, anak akan merasa senang dan riang. Dalam keceriaan permainan anak, disisipkan pelajaran oleh guru agar anak mudah untuk mengerti. Dalam metode ini, anak diajak untuk bermain bersama memainkan alat peraga sebagai objek pembelajaran.

\section{KESIMPULAN}

Penggunaan metode bermain merupakan metode pembelajaran yang efektif sehingga anak membangun pengetahuannya, dapat berinteraksi sosial dengan temannya, bebas tanpa beban dan anak merasa senang, hal ini mendorong anak ikut aktif dalam pembelajaran sehingga dapat meningkatkan perkembangan anak usia dini. 


\section{SARAN}

Berdasarkan hasil penelitian yang diperoleh, maka penulis dapat mengemukakan saran sebagai berikut:

1) Guru hendaknya menggunakan metode pembelajaran yang tepat, menarik, dan menyenangkan agar dapat mendorong minat dan antusias anak dalam mengikuti pembelajaran serta tujuan dapat tercapai dengan baik.

2) Mengingat metode bermain dapat meningkatkan perkembangan anak usia dini, guru hendaknya menerapkan metode ini serta sering melakukan pendekatan secara emosional sehingga anak merasa nyaman dan senang mengikuti pembelajaran.

\section{DAFTAR PUSTAKA}

Arikunto, S. 2005. Manajeman Penelitian. Jakarta: Rineka Cipta.

Budiardjo, Tri. 2011. Pelayanan Anak Yang Holistik. Yogyakarta: ANDI.

Hurlock B. Elizabeth. 1978.

Perkembangan Anak: Jakarta:

Penerbit Erlangga.

Iskandar. 2009. Metode Penelitian Kualitatif. Jakarta: Gaung Persada.

Linda, C. 2006. Metode Praktis Pembelajaran Berbasis Multi Intelegences. Jakarta: Intuisi Pres.

Maryatun, Eka Budi dan Hayati, Nur. 2010. Pengembangan Program Pendidikan Anak Usia Dini. Yogyakarta: Universitas Negeri Yogyakarta

Masitoh, Ocih, Heny, DJ. 2007. Strategi Pembelajaran TK. Jakarta: Universitas Terbuka.

Moeslichataen, R. 2004. Metode Pengajaran Di Taman KanakKanak. Jakarta: PT Rineka. Cipta.

Moleong, Lexy J. 2007 Metodologi Penelitian Kualitatif. Bandung: PT Remaja Rosdakarya Offset.
Mutiah, Diana. 2010. Psikologi Bermain Anak Usia Dini. Jakarta : Kencana Prenada Media Group.

Padmonodewo, Soemiarti. 2000. Pendidikan Anak Prasekolah Jakarta : PT. Rineka Cipta.

Solehudin, 1996. Kurikulum Pendidikan Taman Kanak-Kanak dan Pedoman Penyusunan Silabus. Jakarta : Depdiknas Dirjen Dikti.

Sugiyono. 2012. Metode Penelitian Pendidikan Pendekatan Kuantitatif, Kualitatif, dan $R$ dan $C$. Bandung: Cv Alfabeta.

Sujiono, Yuliani Nurani. 2006. Metode Pengembangan Kognitif. Jakarta: Universitas Terbuka. 2010. Bermain Kreatif Berbasis Kecerdasan Jamak. Jakarta: PT Indeks.

Yus, Anita. 2011. Penilaian Perkembangan Anak Taman KanakKanak. Jakarta: Kencana Prenada Media Group. 